\title{
Evaluation of Bali Cattle Semen Quality During Cryopreservation with Coconut Water-Based Extenders
}

\author{
Ni Made Sawitri ${ }^{1}$, I Gusti Ngurah Bagus Trilaksana ${ }^{2}$ and I Ketut Puja ${ }^{3 *}$ \\ ${ }^{1}$ Postgradutae Student, Faculty of Veterinary Medicine, Udayana University, Bali Indonesia \\ ${ }^{2}$ Department of Animal Reproduction, Faculty of Veterinary Medicine, Udayana University, Bali Indonesia \\ ${ }^{3}$ Veterinary Genetics and Reproduction Technology Laboratory, Faculty of Veterinary Medicine, Udayana University, \\ Bali Indonesia \\ *Corresponding author: asubali@unud.ac.id
}

\begin{abstract}
Article History: 21-265 Received: 17-Jan-21 $\quad$ Revised: 23-Apr-21 $\quad$ Accepted: 27-May-21
\section{ABSTRACT}

The aim of this research was to evaluate the Bali cattle semen quality during cryopreservation with different types of extenders in term of live, total motility, progressive motility, and abnormality of post-thawed bull sperms. The treatments were AndroMed® (T0), Tris-based egg yolk diluent (T1), Tris-based coconut water diluent (T2), Coconut water egg yolk diluent (T3). Bulls' semen was collected from two adult Bali cattle maintained at the semen production facility at Bali Artificial Insemination Center, Tabanan Bali. The age of the bulls were 6 years old. Sperm live, total motility, progressive motility, and abnormality were analyzed with computer assisted sperm analysis (CASA) postdilution, before and after thawed. The study was replicated five times, and data were analyzed using analysis of variance (ANOVA). The results showed that AndroMed ${ }^{\circledR}$ and Tris-based egg yolk had significantly higher sperm live, total motility, progressive motility and abnormalities of spermatozoa for post-dilution, after equilibration and post thawed than Tris egg yolk coconut water and Coconut water egg yolk diluent. It was concluded that AndroMed® and Tris-based egg yolk can be considered as the best suitable extender for Bali cattle sperm cryopreservation. Coconut water had a deleterious effect when supplemented with $20 \%$ in tris and egg yolk.
\end{abstract}

Key words: Bali cattle, Coconut water, Cryopreservation, Sperm, Quality.

(202I IJVS - All Rights Reserved

\section{INTRODUCTION}

With the inability of national meat production to meet the demand for beef in Indonesia, the government necessitating imports of live cattle from abroad. Of course, this is an indication that beef production is still not on target. Hence, the Indonesian government introducing special program to increase the population and livestock production for meat self-sufficiency. In 2017 , the government launched a program to increase the population through the artificial insemination program called 'Sapi Indukan Wajib Bunting (UPSUS SIWAB). This program was a special effort to accelerate the increased population of pregnant with artificial insemination (AI). In 2020, the government launched the SIKOMANDAN (Buffalo Cattle Commodity Mainstay of the Country) program. With this program, productive cows and buffalo are ensured to be mated, either through artificial insemination or natural mating.

Artificial Insemination is one assisted reproduction technology in which sperm are collected from the superior bull, processed, preserved, and artificially placed into the female reproductive tract at the proper time for purpose of conception (Patel et al. 2017). The success rate of artificial insemination may be influenced by several factors, such as the profile of the technicians and the practices used (Ybanez et al. 2017), the quality of frozen semen (Haris et al. 2020), and cattle recipient.

Frozen semen quality is one of factor that affect the success rate of artificial insemination. The physical properties and biochemical properties of semen were affected by different steps of freezing (Hussain et al. 2016). The frozen semen quality affected by the type and composition of extenders used, the semen production process, the implementation of artificial insemination, temperature and the length of storage.

Cite This Article as: Sawitri NM, Trilaksana IGNB and Puja IK, 2021. Evaluation of Bali cattle semen quality during cryopreservation with coconut water-based extenders. International Journal of Veterinary Science 10(4): 329-334. https://doi.org/10.47278/journal.ijvs/2021.064 
The extender has a very vital role in the post-thaw fertility of semen (Rehman et al. 2013). Semen extender is used for providing nutrients, protection of sperm cells against various shocks during processing, cooling buffer, protecting sperm from bacteria. The extenders contain an ingredient that maintains osmosis pressure, electrolyte balance, the supply of food and energy sources, providers of a buffer and inhibits microbial growth. Various semen components that combine in a perfect medium are needed to make semen retain its natural properties and can prolong life from the initial process to the freezing and post-thawing processes (Chung et al. 2019). For this purpose, there is need of good quality semen extenders which plays an indispensable role in improving the quality of post-thawing semen in terms of sperm motility, viability, plasma membrane and damage at the DNA level (Raheja et al. 2018).

Recently, many of semen extenders are developed and practiced all over the world for semen freezing purposes. Some known extenders used animal protein egg-yolk and plant protein source containing extenders. In bovine, most extenders contain $20 \%$ of egg yolk or a substitute of the same in composition. Egg yolk is a basic ingredient for the use of bovine semen extender. Egg yolk provides an excellent protection sperm against initial cold shock. However, egg yolk has biosecurity risks (Anzar et al. 2019). The semen diluents with egg yolk substitutes, being recently available for freezing bull semen and were successfully tested to improve cryopreserved bull semen quality characteristics while eliminating the abovementioned egg yolk component disadvantages. The plant protein source-based extender is developed recently with more benefits i.e., free of transboundary diseases and good conception rate (Raheja et al. 2018). Previous studies performed by El-Sheshtawy et al. (2017), Puja et al. (2018) and Baldaniya et al. (2020) showed that coconut water-based extenders can be efficiently used as alternatives to the removal of animal-based extenders in frozen semen.

In Bali cattle, no information on the cryo-survival of spermatozoa during cryopreservation with coconut water extender. Therefore, the objective of this research was to assess the effect of semen extenders containing coconut water with Tris or combined with egg yolk on the viability of spermatozoa.

\section{MATERIALS AND METHODS}

\section{Semen Collection}

Semen from two Bali cattle bulls 6-7 years old and clinically normal were used in this study. Semen was collected by artificial vagina once a week. Semen ejaculates were incubated in a $37^{\circ} \mathrm{C}$ water bath and initially evaluated for sperm motility, progressive motility and concentration. Semen volume was determined by a graded collection tube, concentration was calculated with a photometer (Minitube $\mathrm{GmbH}$, Tiefenbach, Germany). All procedures were carried out by the approval of the Animal Care Committee of the Faculty of Veterinary Medicine, Udayana University, Bali Indonesia.

\section{Assessment of Sperm Motility}

Progressive motility and motility were determined by a computer-assisted sperm analyzer (CASA; IMV, France). The samples with more than $80 \%$ progressive motility and $80 \%$ morphologically normal spermatozoa were included in the study. For each assessment, six different fields were analyzed under the microscope.

\section{Semen Extender}

This experiment was designed to assess if treatment of bull sperm with a tender coconut-based extender can be use during cryopreservation of Bali cattle semen. Four different extenders were used in this study: (1) Commercial extender AndroMed $®$ (T0), Tris-based egg yolk diluent (T1), Tris-based coconut water diluent (T2), Coconut water egg yolk diluent (T3) (Table 1).

\section{Preparation of Coconut Water}

Coconut water $(\mathrm{CW})$ was collected on the day of the experiment from tender, green, healthy, and undamaged coconut fruits. The coconut water collected from coconut fruits was first filtered through Whatman filter paper no. 4. Then, it was centrifuged at least for 5 minutes at 3000 rpm in a centrifuge machine and the supernatant from each tube was obtained carefully in a sterile glass bottle.

\section{Research Design}

Experimental design used in this study was an experiment in a completely randomized factorial design with 4 factors. The first factor was AndroMed® (T0), Tris-based egg yolk diluent (T1), Tris-based coconut water diluent (T2), and Coconut water egg yolk diluent (T3). The second factor was the time of processing which consisted of 3 treatments, including after dilution (T3), before freezing, and after freezing. Split ejaculates were prepared and extended separately with each extender, so that, both extenders were represented in each ejaculate from each bull. The extension rate was determined based on ejaculate volume, sperm progressive motility, sperm concentration $/ \mathrm{ml}$, and the packaging-unit capacity $(0.25 \mathrm{ml}$ straws). Calculations were made, so that, each insemination

Table 1: Composition of extenders used for cryopreservation of Bali cattle bull semen

\begin{tabular}{|c|c|c|c|c|}
\hline & $\begin{array}{l}\text { Tris-based egg } \\
\text { yolk diluent }\end{array}$ & $\begin{array}{l}\text { Tris-based coconut } \\
\text { water diluent }\end{array}$ & $\begin{array}{l}\text { Coconut water } \\
\text { egg yolk diluent }\end{array}$ & AndroMed® \\
\hline Fructose & $1 \mathrm{~g}$ & $1 \mathrm{~g}$ & & \multirow{9}{*}{$\begin{array}{l}\text { Phospholipids TRIS, Citric acid, Antioxidants, } \\
\text { Buffers, Glycerol, purest Water, Gentamycin, } \\
\text { Tylosin, Spectinomycin, and Lincomycine }\end{array}$} \\
\hline Tris & $3.025 \mathrm{~g}$ & $3.025 \mathrm{~g}$ & & \\
\hline Egg Yolk & $20 \%$ & - & $20 \%$ & \\
\hline Citrate acid & $1.675 \mathrm{~g}$ & $1.675 \mathrm{~g}$ & & \\
\hline Coconut water & & $20 \%$ & $80 \%$ & \\
\hline Penicillin & $50.000 \mathrm{IU}$ & $50.000 \mathrm{IU}$ & $50.000 \mathrm{IU}$ & \\
\hline Streptomycin & $1 \mathrm{mg} / \mathrm{ml}$ & $1 \mathrm{mg} / \mathrm{ml}$ & $1 \mathrm{mg} / \mathrm{ml}$ & \\
\hline Ultrapure water & Add until $100 \mathrm{ml}$ & $1 \mathrm{mg} / \mathrm{ml}$ & $1 \mathrm{mg} / \mathrm{ml}$ & \\
\hline $\mathrm{pH}$ & 6.8 & 6.8 & 6.8 & \\
\hline
\end{tabular}


dose contained $20 \times 10^{6}$ motile spermatozoa/ straw before freezing. The semen samples were cooled $\left(4^{\circ} \mathrm{C}\right)$ and equilibrated for $4 \mathrm{~h}$. Finally, the straws being exposed to the liquid nitrogen for the final freeze. For post-thaw evaluation, frozen straws were thawed in a water bath at $37^{\circ} \mathrm{C}$ for 30 seconds.

\section{RESULTS}

\section{Characteristics of Fresh Semen}

The semen volume of bull with a mean value of 6.44 $\mathrm{ml}$. The color showed variation from milky (1) to creamy grainy (3). The mean semen concentration was 1.242 billion sperm cells per $\mathrm{ml}$. The mean of total motility showed $86.20 \%$. The $\mathrm{pH}$ was $6.52 \pm 0.00$. The mean of progressive motility was $76 \%$. The live percentage observed for sperm cells was $91.20 \%$. The observation results for primary abnormality in sperm cells was $0.86 \%$ (Table 2).

\section{Semen Quality During Cryopreservation}

The average sperm live in four types of extender at post-dilution, pre- and post- freezing were 88.86, 76.24 and 63.25, respectively, for T0 (AndroMed®). It is followed by Tris-based egg yolk diluent (T1), with a rate of $84.12,80.06$, and 70.43 , in Tris-based coconut water diluent (T2) rate of $87.25,69.22$, and 58.68. Then in Coconut water egg yolk diluent (T3) rates of 85.76, 73.04, and 59.17, respectively. The sperm live in T0, T1, T2, and T3, declined after the semen was added with extenders. Among the four extenders used, Tris-based egg yolk diluent (T1) exhibited a little effect on the decrease than those other extenders (Table 3). The type of diluents effect on live percentage was significant $(\mathrm{P}<0.05)$. Trisbased egg yolk diluent were the type of diluent that had the lowest reduction.

The type of diluent affected the total motility of semen significantly $(\mathrm{P}<0.05)$. The total motility of semen in four types of extender at post-dilution, pre- and postfreezing was 83.83, 75.97 and 62.02, respectively, for T0 (AndroMed $\AA$ ). The total motility of semen in Tris-based egg yolk diluent (T1), at post-dilution, pre- and post- post freezing were $82.84,78.39$, and 62.29 , respectively. In Tris-based coconut water diluent (T2) at post-dilution, pre- and post- freezing were 82.22, 66.42, and 50.17, respectively. Total spermatozoa motility in Coconut water egg yolk diluent (T3) at post-dilution, pre- and postfreezing were 82.68, 68.50, and 51.73, respectively. Among the four diluents, it showed that Tris-based egg yolk diluent (T1) had little effect on decreasing the total motility of semen (Table 4).

The progressive sperm motility was significantly $(\mathrm{P}<0.05)$ affected by the type of extenders. A significant decrease $(\mathrm{P}<0.05)$ in the percentage of progressive motility in four types of extenders. The progressive motility of semen in four types of extender at postdilution, pre- and post-freezing was 72.02, 67.82 and 54.26, respectively, for T0 (AndroMed®). The progressive motility of sperm in Tris-based egg yolk diluent (T1), at post-dilution, pre- and post- freezing were 71.77, 66.77 and 54.86, respectively. Tris-based coconut water diluent (T2) at post-dilution, pre- and post- freezing were 64.12, 41.11, and 29.99, respectively. The progressive motility of sperm in Coconut water egg yolk diluent (T3) at post-dilution, pre- and post- freezing was $71.53,39.85$, and 31.25 , respectively. Among the four diluents, it showed that Tris-based egg yolk diluent (T1) and AndroMed ${ }^{\circledR}$ (T0) had the least effect on the decrease in the percentage of progressive motility of sperm (Table $5)$. There was a nonsignificant $(\mathrm{P}>0.05)$ decrease in percentage of progressive motility sperms in T0 (AndroMed®) when compared with T1 (Tris-based egg yolk diluent (T1).

The abnormality parameter observed in this study was only the abnormalities in the tail of spermatozoa. The type of extenders affected the abnormalities of semen significantly $(\mathrm{P}<0.05)$. The sperm abnormalities mean values were higher in Tris-based coconut water diluent (T2) and Tris-based coconut water diluent (T2) (Table 5). In both extenders, the sperm abnormalities mean value was more than $20 \%$. There were nonsignificant $(\mathrm{P}>0.05)$ sperm abnormalities in $\mathrm{T} 0$ (AndroMed®) extenders when compared with T1 (Trisbased egg yolk diluent).

Table 2: Effect of different extender and storage duration on a live percentage (\%)

\begin{tabular}{lccc}
\hline Groups & Post Dilution & Pre-Freezing & Post-Freezing \\
\hline AndroMed® (T0) & $88.86 \pm 0.92$ & $76.24 \pm 0.41$ & $63.25 \pm 0.28$ \\
Tris-based egg yolk diluent (T1) & $84.12 \pm 0.17$ & $80.06 \pm 0.26$ & $70.43 \pm 0.49$ \\
Tris-based coconut water diluent (T2) & $87.25 \pm 0.26$ & $69.22 \pm 0.36$ & $58.68 \pm 0.44$ \\
Coconut water egg yolk diluent (T3) & $85.76 \pm 0.71$ & $73.04 \pm 0.55$ & $59.17 \pm 0.45$ \\
\hline
\end{tabular}

Table 3: Effect of different extender and storage duration on total motility (\%)

\begin{tabular}{lccc}
\hline Groups & Post Dilution & Pre-Freezing & Post Freezing \\
\hline AndroMed® (T0) & $83.83 \pm 0.17$ & $75.97 \pm 0.58$ & $62.02 \pm 0.72$ \\
Tris-based egg yolk diluent (T1) & $82.84 \pm 0.97$ & $78.39 \pm 0.48$ & $62.29 \pm 0.65$ \\
Tris-based coconut water diluent (T2) & $82.22 \pm 0.47$ & $66.42 \pm 0.61$ & $50.17 \pm 0.17$ \\
Coconut water egg yolk diluent (T3) & $82.68 \pm 0.68$ & $68.50 \pm 0.46$ & $51.73 \pm 1.0$ \\
\hline
\end{tabular}

Table 4: Effect of different extender and storage duration on progressive sperm motility (\%)

\begin{tabular}{lccc}
\hline Groups & Post Dilution & Pre-Freezing & Post Freezing \\
\hline AndroMed ${ }^{(T 0)}$ & $72.02 \pm 0.64$ & $67.82 \pm 0.49$ & $54.26 \pm 0.44$ \\
Tris-based egg yolk diluent (T1) & $71.77 \pm 1.47$ & $66.77 \pm 1.07$ & $54.86 \pm 0.59$ \\
Tris-based coconut water diluent (T2) & $64.12 \pm 0.37$ & $41.11 \pm 0.72$ & $29.99 \pm 0.37$ \\
Tris-based coconut water diluent (T2) & $71.53 \pm 1.14$ & $39.85 \pm 0.85$ & $31.25 \pm 0.82$ \\
\hline
\end{tabular}


Int J Vet Sci, 2021, 10(4): 329-334.

Table 5: Effect of different extender and storage duration on abnormality (\%)

\begin{tabular}{lccc}
\hline Groups & Post Dilution & Pre-Freezing & Post Freezing \\
\hline AndroMed® (T0) & $0.86 \pm 0.08$ & $0.86 \pm 0.05$ & $0.90 \pm 0.07$ \\
Tris-based egg yolk diluent (T1) & $0.88 \pm 0.04$ & $0.92 \pm 0.04$ & $0.92 \pm 0.04$ \\
Tris-based coconut water diluent (T2) & $13.39 \pm 0.56$ & $16.04 \pm 0.37$ & $20.80 \pm 0.70$ \\
Coconut water egg yolk diluent (T3) & $14.83 \pm 0.66$ & $17.04 \pm 0.45$ & $21.34 \pm 0.45$ \\
\hline
\end{tabular}

\section{DISCUSSION}

\section{Characteristics of Fresh Semen}

The results of the evaluation of fresh semen parameters such as volume, concentration, total motility, viability, and primary abnormalities and $\mathrm{pH}$ were showed corresponding characteristics to most of Bali cattle bull semen quality in general. The average volume of semen in this study was higher than the average volume of semen for Balinese cows in Lampung (Savitri et al. 2014) and Balinese cattle raised in BIB Singosari (Prastowo et al. 2018). The nature of semen is influenced by the age of the male. Age has a significant effect on the volume of ejaculate and percentage of motile spermatozoa. The variation in volume in Bali cattle is probably due to the age of the cows for which semen is collected (Argiris et al. 2018) as well as by the climate during harvest (D'Andre et al. 2018).

The sperm concentration of Bali cattle in this study is slightly different from the results of observations of Balinese cattle in Singosari, which have semen concentrations of $1128.77 \times 10^{6}$ spermatozoa per $\mathrm{ml}$ (Prastowo et al. 2019) and 1044. 178 $\times 10^{6}$ spermatozoa per $\mathrm{ml}$ (Novianti et al. 2020). Sperm concentration is influenced by the age of the bulls (Nirwana and Suparman 2017; Bayu et al. 2020) and the spermatozoa progressive motility in this study was $75 \%$.

The Progressive semen motility in this study was higher than Bali cattle raised in Nusa Tenggara Timur with an individual movement average of $70 \%$ (MataHine et al. 2014) and Balinese cattle raised in Sulawesi (Nirwana and Suparman 2017). This difference in progressive motility is caused by the age of different males (Bayu et al. 2019).

The primary abnormality in the form of tail abnormalities observed in fresh semen from Bali cows was $0.86 \%$. Observations of primary abnormalities in these spermatozoa are very low. The percentage of spermatozoa that have primary abnormalities ranges from 0-2.86\% (Prastowo et al. 2018). The primary abnormality most commonly found in cattle was simple bent tails with an average of $4.42 \%$. Primary abnormalities are influenced by male age (Sitali et al. 2017).

\section{Semen Quality During Cryopreservation}

Semen cryopreservation is principally used to store sperm, which is very important in cattle production. Although semen freezing technology in cattle is very developed compared to other species, it appears that there are still gaps in knowledge and technology related to semen quality after freezing (Ugur et al. 2019). In this study, four types of extenders were compared whose composition acts as a buffer, an energy source, and a cryoprotectant. All ingredients in these extenders are designed to protect by providing an optimal environment for spermatozoa.
AndroMed® diluent is a commercial diluent that contains lipoproteins derived from soybeans. Diluents containing coconut water can provide the physical and chemical needs of spermatozoa so that they can maintain the fertility and viability of spermatozoa (El-Sheshtawy et al. 2017).

In this study, the sperm viability in four types of diluent showed gradually decreased over the freezing process. The four types of diluents are quite effective in maintaining sperm viability against cold stress and in the freezing process. Egg yolk Tris Citrate diluent showed the best results. The percentage of sperm viability in this diluent was $70 \%$, slightly higher than AndroMed® diluent. The percentage of sperm viability of Bali cattle in this study was higher than the sperm viability in Simmental cattle (45.17\%) (Yendraliza et al. 2019). This difference in viability was due to the difference in diluent composition. The lipoprotein content of Tris citrate diluent in egg yolk and lipoprotein from soybeans in AndroMed ${ }^{\circledR}$ diluent are effective components in maintaining viability during the fast-cooling process.

The total sperm motility of Bali cattle in the four diluents after freezing still showed good quality. The percentage of total sperm motility in the four diluents in this study ranged from 58-62\%. This showed that the diluent composition is quite effective in maintaining the total sperm motility of Bali cattle.

This study was found a significant effect of extender on progressive sperm motility. The results of this study showed that AndroMed $®$ diluent and Tris citrate yolk was an optimal role in maintaining sperm motility. These diluents can maintain the progressive sperm motility above the SNI (National Standard of Indonesia, 2017) standard. According to SNI. 4869-1-2017, the quality of cattle semen after undergoing the freezing process must contain at least $40 \%$ live and motile spermatozoa. These results indicated that the progressive sperm motility in this study following the provisions of SNI. 4869-1-2017 (BSN. SNI. 4869-1-2017) and this agreed with the findings of Kalonji et al. (2017) egg yolk-based diluent is a good diluent for maintaining spermatozoa motility compared to coconut water. Also, this study agreed with the findings of Ghareeb et al. (2017) that stated AndroMed $\AA$ can be considered as the best suitable extender for bull sperm cryopreservation. An increase in the progressive sperm motility in this study was suspected by the composition of the extender with fructose as a source of energy to maintain the viability of spermatozoa during cryopreservation also egg yolk as an extracellular cryoprotectant which protects the motility of sperm (Bencharif et al. 2010).

In this study, the tris coconut water extenders and egg yolk coconut water showed that the progressive sperm motility below the eligibility standard of SNI. The incidence of tail abnormalities was higher in these extenders. The less progressive sperm motility in this 
study was due to the large number of spermatozoa having abnormalities in the tail. Sperm motility is generated through activation of the spermatozoa flagella, whose core structure, axoneme, resembles vibrating cilia. Also, the axonemal structure requires a variety of accessory structures to support the integrity of the spermatozoa tail (Lehti and Sironen 2017). These abnormalities in the tail may be associated with higher supplemented coconut water in extenders. The motility degeneration rate was observed in extenders supplemented with $20 \%$ coconut water in tris egg yolk citrate extender. This was due to the harmful effect of coconut water in tris egg yolk citrate extender when supplemented at a higher concentration (Baldaniya et al. 2020).

\section{Conclusion}

It was concluded that the highest progressive sperm motility was found in AndroMed $®$ and Tris amino methane egg yolk was further maintained above $40 \%$ and following the provisions of SNI. 4869-1-2017. AndroMed ${ }^{\circledR}$ and Tris amino methane egg yolk can be considered as the best suitable extender for Bali cattle sperm cryopreservation. Coconut water had a deleterious effect as an additive when supplemented with $20 \%$ in tris and egg yolk.

\section{Author's Contribution}

NMS and IKTP designed, executed, analyzed the data, and wrote the manuscript. IGNBT assisted in the design and execution of the research. All authors have read and approved the manuscript.

\section{Acknowledgement}

Authors extremely thankful to Bali Artificial Insemination Center, Tabanan Bali, Indonesia for their permission to perform this research.

\section{REFERENCES}

Anzar M, Rajapaksha K and Boswall L, 2019. Egg yolk-free cryopreservation of bull semen. PLoS ONE 14: e0223977. https://doi.org/10.1371/journal.pone.0223977

Argiris A, Ondho YS, Santoso SI and Kurnianto E, 2018. Effect of age and bull on fresh semen quality and frozen semen production of Holstein bulls in Indonesia. IOP Conf. Series: Earth and Environmental Science 119: 012033. https://doi.org/10.1088/1755-1315/119/1/012033

Baldaniya RV, Chaudhari NF, Modi LC, Patel CM, Puri G and Patel JM, 2020. Effect of coconut water in tris egg yolk citrate extender on cauda epididymal buck spermatozoa motility preserved at refrigeration temperature. Indian Journal of Animal Health 59: 55-61. https://doi.org/ 10.36062/ijah.59.1.2020.55-61

Bayu S, Isnaini $\mathrm{N}$ and Adie SI, 2020. Influence of bull age on fresh semen traits of Bali cattle. Russian Journal of Agricultural and Socio-Economic Sciences 98: 27-30. https://doi.org/10.18551/rjoas.2020-02.04

Bencharif DL, Amirat-Briand A, Garand M, Anton E, Schmitt S, Desherces G, Delhomme ML, Langlois P, Barrière and Destrumelle S, 2010. Freezing canine sperm: Comparison of semen extenders containing Equex ${ }^{\circledR}$ and LDL (Low Density Lipoproteins). Animal Reproduction Science 119: 305-313. https://doi.org/10.1016/j.anireprosci.2010.01.009

BSN (Badan Stardarisasi Nasional), 2017. SNI 4869-1:2017. Semen Beku-Bagian 1: Sapi. Badan Standarisasi Nasional. Jakarta.
Chung ELT, Nayan N, Nasir NSM, Hing PSA, Ramli S, Rahman MHA and Kamalludin MH, 2019. Effect of honey as an additive for cryopreservation on bull semen quality from different cattle breeds under tropical condition. Journal of Animal Health and Production 7: 171-178. https://doi.org/10.17582/journal.jahp/2019/7.4.171.178

D'Andre HC, Rugira KD, Elyse A, Claire I, Vincent N, Celestin M, Maximillian M, Tiba M, Pascal N, Marie NA, Christine $\mathrm{K}$ and Daphrose G, 2017. Influence of breed, season, and age on quality bovine semen used for artificial insemination. International Journal of Livestock Production 8: 72-78. https://doi.org/10.5897/IJLP2017.0368

El-Sheshtawy RI, El-Nattat WS and Ali GAD, 2017. Cryopreservation of cattle semen using coconut water extender with different glycerol concentrations. Asian Pacific Journal Reproduction 6: 279-282. https://doi.org/ 10.4103/2305-0500.217343

Ghareeb S, Haron W, Yusoff R, Yimer N, Baiee F, Ahmedeltayeb $\mathrm{T}$ and Ebrahimi M, 2017. Post-thaw evaluation of cryopreserved bull semen extended in four different semen extenders. Australian Journal of Basic and Applied Sciences 11: 80-87.

Haris FZ, Ondho YS and Samsudewa D, 2020. Effect of vitamin $\mathrm{E}$ addition to frozen Simmental bull semen extender on post-thawing quality. E3S Web of Conferences 142: 02002. https://doi.org/10.1051/e3sconf/202014202002

Hussain SO, Shahad HK and Al-Badry KI, 2016. Effect of dilution, cooling, and freezing on physical and biochemical properties of semen for Holstein bull born in Iraq Advances in Animal and Veterinary Sciences 4: 575-579. https://doi.org/10.14737/journal.aavs/2016/4.11.575.579

Kalonji MPV, Nethenzheni LP, Ajao OA and Barry DM, 2017. Storage of Nguni bull semen extended in coconut water and soybean milk in tris extender. Veterinary Science \& Technology 8 (Suppl): 7. https://doi.org/10.4172/21577579-C1-034

Lehti MS and Sironen A, 2017. Formation and function of sperm tail structures in association with sperm motility defects. Biology of Reproduction 97: 522-536. https://doi.org/10.1093/biolre/iox096

MataHine T, Burhanuddin and Marawali A, 2014. Efektivitas air buah lontar dalam mempertahankan motilitas, viabilitas dan daya tahan hidup spermatozoa sapi bali. Jurnal Veteriner 15: 263-273.

Nirwana and Suparman, 2017. The effect of males age on the quality of Bali cattle fresh semen. Chalaza Journal of Animal Husbandry 2: 13-18. https://doi.org/10.31327/ chalaza.v2i2.296

Novianti I, Purwantara B, Herwijanti E, Nugraha CD, Putri RF, Furqon A, Septian WA, Rahayu S, Nurgiartiningsih VMA and Suyadi S, 2020. Effect of breeds on semen characteristics of aged bulls in the Indonesian National Artificial Insemination Center. Jurnal Ilmu-Ilmu Peternakan 30: 173-179. https://doi.org/10.21776/ub.jiip.2020.030.02. 10

Patel GK, Haque N, Madhavatar M, Chaudhari AK, Patel DK, Bhalakiya N, Jamnesha N, Patel P and Kumar R, 2017. Artificial insemination: A tool to improve livestock productivity. Journal of Pharmacognosy and Phytochemistry SP1: 307-313.

Prastowo S, Dharmawan P, Nugroho T, Bachtiar A, Lutojo and Pramono A, 2018. Kualitas semen segar sapi bali (Bos javanicus) pada kelompok umur yang berbeda. Jurnal Ilmu Ternak 18: 1-8. https://doi.org/10.24198/jit.v18i1.17684

Prastowo S, Widyas N, Ratriyanto A, Kusuma MST, Dharmawan P, Setiawan IA and Bachtiar A, 2019. Individual variance component of fresh semen quality in Bali cattle (Bos javanicus) Bull. IOP Conf. Series: Earth and Environmental Science 372: 012025. https://doi:10.1088/ 1755-1315/372/1/012025 
Int J Vet Sci, 2021, 10(4): 329-334.

Puja IK, Sawitri NM, Maharani N, Gunawan IWNF and Heryani LGSS, 2018. A comparative study on the effects of coconut water based extenders on the quality of Kintamani dog semen preserved at $4^{\circ} \mathrm{C}$. Advances in Animal and Veterinary Sciences 6: 192-196. https://doi.org/10.17582/ journal.aavs/2018/6.5.192.196

Raheja N, Choudhary S, Grewal S, Sharma N and Kumar N, 2018. A review on semen extenders and additives used in cattle and buffalo bull semen preservation. Journal of Entomology and Zoology Studies 6: 239-245.

Rehman F, Zhao C, Shah MA, Qureshi MS and Wang X, 2013. Semen extenders and artificial insemination in ruminants. Veterinaria 1: 1-8.

Savitri FK, Suharyati S and Siswanto, 2014. Kualitas semen beku sapi bali dengan penambahan berbagai dosis vitamin C pada bahan pengencer skim kuning telur. Jurnal Ilmiah Peternakan Terpadu 2:30-36. http://doi.org/10.23960/jipt. v2i3.p\%25p

Sitali MC, Mwanza AM, Mwaanga ES, Parsons IR and Parsons NJ, 2017. Sperm morphology and sperm quality of bulls raised on commercial farms in Zambia. International Journal of Advanced Biological Research 7: 27-33.

Ugur MR, Saber Abdelrahman A, Evans HC, Gilmore AA, Hitit M, Arifiantini RI, Purwantara B, Kaya A and Memili E, 2019. Advances in cryopreservation of bull sperm. Frontiers in Veterinary Science 6: 268. https://doi.org/ 10.3389/fvets.2019.00268

Ybanez AP, Ybanez RHD, Caindec MO, Mani LV, Abela JV, Nunez ES, Royo JT and Lopez IFM, 2017. Profile and artificial insemination practices of technicians and the artificial insemination success rates in Leyte, Samar, and Biliran, Philippines (2011-2015). Veterinary World 10: 181-186. https://doi.org/10.14202/vetworld.2017.181-186

Yendraliza Y, Hendriyanto Y, Mucra DA, Zumarni and Rodialla M, 2019. The recovery rate of Simental spermatozoa frozen of post thawing by using tris dilution with different egg yolks. IOP Conf. Series: Earth and Environmental Science 391: 012008. https://doi.org/10.1088/1755-1315/391/1/ $\underline{012008}$ 